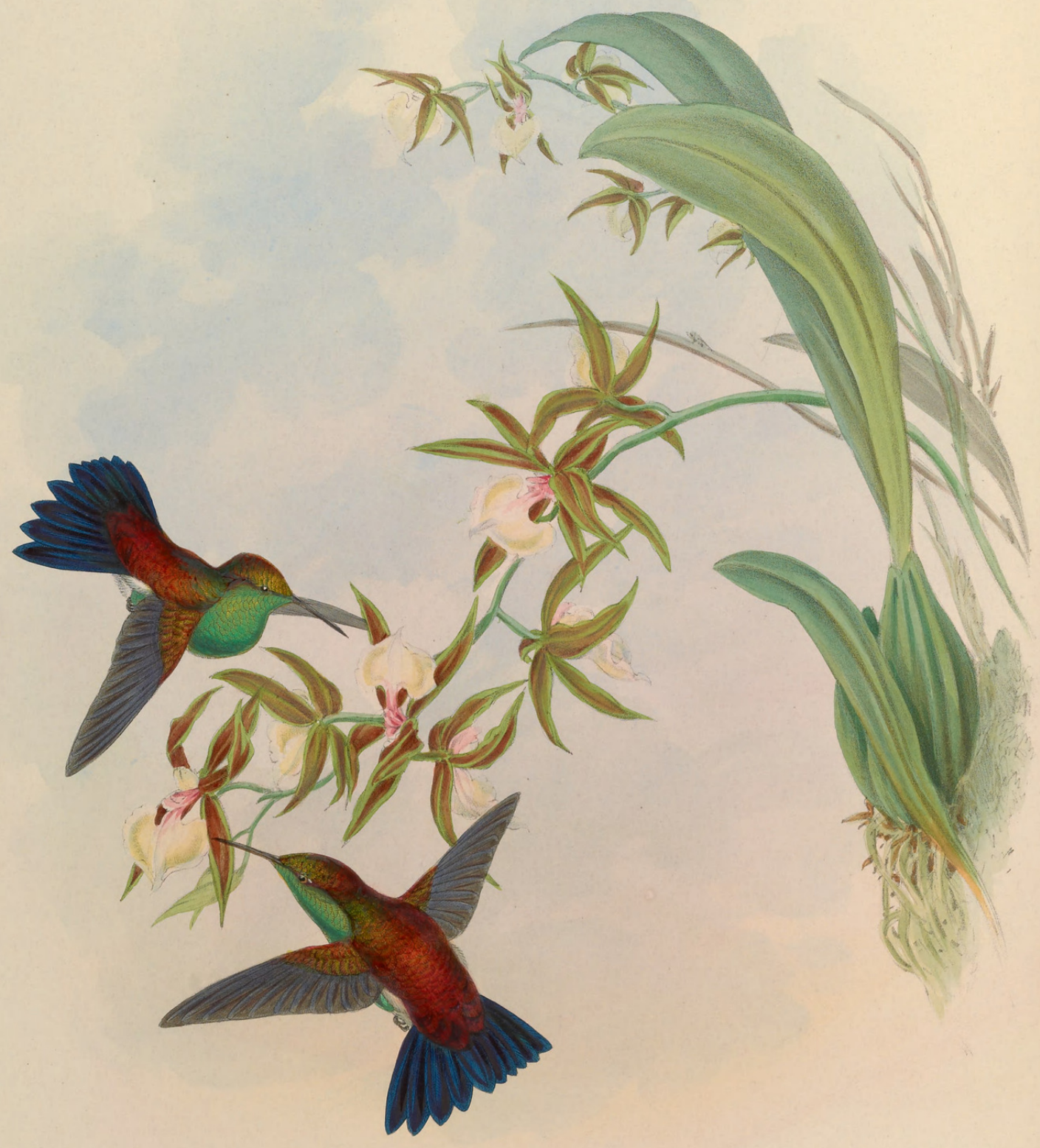




\section{ERYTHRONOTA ANTIQUA.}

\section{Erythronote.}

Ornismya erythronotos, Less. Hist. Nat. des Ois.-Mou., p. 181. pl. 61.-Ib. Tab. des Esp. d'Ois.Mou., p. xxxii.-Ib. Ind. Gen. et Syn. des Ois. du Gen. Trochilus, p. xxviii.

erythronotus, Less. Rev. Zool. 1839, p. 19.

Polytmus erythronotus, Gray and Mitch. Gen. of Birds, vol. i. p. 109, Polytmus, sp. 78.

Saucerottia erythronota, Bonap. Consp. Gen. Av., p. 77, Saucerottia, sp. 2.-Reichenb. Auf. der Col., p. 8.-Bonap. Rev. et Mag. de Zool. 1854, p. 255.

Trochilus erythronotus, Jard. in Ann. and Mag. Nat. Hist., vol. xx. p. 374.

ARE we to regard the several birds generally known under the name of Erythronotes as one or as many species? Great care is required at the hand of the ornithologist respecting this peculiar section of the Trochilidæ. In every group of birds which the monographer attempts to illustrate, some one or two species will be found to vary, or sport as it were, in their size and colouring more than others ; fortunately, however, these are the exceptions, and not the rule. I may ask, is the great bird from Tobago the same as the more diminutive bird from Trinidad? Again, is the bird from the Caraccas, which is of the same size as that from Trinidad, but from which it differs in having bright chestnut under tail-coverts, the same? Or are we to regard them as so many species? For the present, I believe it will be better to consider them identical, for this reason: I find that the specimens from Trinidad differ very considerably among themselves, some having beautiful violet-grey under tail-coverts, while in others those feathers are uniform chestnut, and in others again they are olive-grey; it is clear, therefore, that the difference in the colouring of these feathers cannot be regarded as of importance. In making these remarks, it must be understood that I exclude the bird to which M. Bourcier has given the name of Felicic - - a bird most nearly allied, but which has never, I believe, any red colouring on the nape and back,-a feature found in all those previously noticed, whether from Trinidad, Tobago, or the Caraccas. The figures in the accompanying Plate were taken from Trinidad specimens to which I would apply the term antiqua, as being the oldest known. If future research should discover good grounds for separating the larger Tobago birds, they might receive a new specific name, as indeed may the other also. In the imperfect state of our knowledge, I feel that I am right in placing them together, and I do this with a strong bias to the opinion that they will never be separated. With regard to the Trinidad bird, but little has been recorded respecting it. Mr. Tucker informed me that it is very common all over the island, inhabiting the woods as well as the savannahs, but more frequently the latter, visiting almost every flower that comes in its way. In the twentieth volume of the 'Annals and Magazine of Natural History,' above referred to, Sir William Jardine, quoting from Mr. Kirk's notes on the Tobago bird, says: "begins to build about the 10th of February, generally on a small stalk, or on the upper side of some twig, sometimes so hidden from the eye by a large leaf as to preclude all possibility of seeing it from above, and often so near the ground as to remain undiscovered : makes a small nest, in which it lays two pure white eggs." Lesson, I believe, is quite wrong in giving Brazil as the habitat of this bird, for I have no reason to suppose that it is ever found there.

Not much difference occurs in the plumage of the sexes, and the young at an early age assume the adult livery, or a dress very similar to it.

Forehead yellowish shining green; crown and nape, back, wing- and tail-coverts coppery red; wings purplish brown; tail black, with steel-blue reflexions; back of the neck green; breast and under surface phining grass-green ; under tail-coverts rufous violet or grey; on each side the flanks an oblong patch of white; bill black, with a lighter base to the under mandible, that part appearing to have been fleshcolour.

The figures are of the size of life. The plant is the Odontoglossum hastilabium, var. fuscatum. 


\section{$2 \mathrm{BHL}$ Biodiversity Heritage Library}

Gould, John. 1861. "Erythronota antiqua, Erythronote. [PI. 316]." A monograph of the Trochilidoe, or family of humming-birds 5, https://doi.org/10.5962/p.317125.

View This Item Online: https://www.biodiversitylibrary.org/item/108806

DOI: https://doi.org/10.5962/p.317125

Permalink: https://www.biodiversitylibrary.org/partpdf/317125

\section{Holding Institution}

Smithsonian Libraries

\section{Sponsored by}

Smithsonian Institution Libraries

\section{Copyright \& Reuse}

Copyright Status: NOT_IN_COPYRIGHT

This document was created from content at the Biodiversity Heritage Library, the world's largest open access digital library for biodiversity literature and archives. Visit BHL at https://www.biodiversitylibrary.org. 